\title{
Severe Outbreak of Stemphylium Leaf Blight, a New Disease of Cotton in Brazil
}

\author{
Y. R. Mehta, Instituto Agronômico do Paraná-IAPAR, Caixa Postal 481, CEP-8600-970, Londrina, PR., Brazil
}

\begin{abstract}
Mehta, Y. R. 1998. Severe outbreak of Stemphylium leaf blight, a new disease of cotton in Brazil. Plant Dis. 82:333-336.

A severe epidemic of a leaf blight of cotton occurred in the state of Paraná, Brazil, during 1994 and 1995, causing up to $100 \%$ yield losses in some commercial fields of cultivar Paraná 3 . The severity of the disease among fields was variable and cultivar-dependent. Attempts were made to identify the organism causing the leaf blight symptoms, which were characterized as circular to irregular dark brown to black spots turning reddish brown with age and varying between 2 and $10 \mathrm{~mm}$ in diameter. The older lesions showed cracks and/or holes in the center. Severely diseased leaves dried rapidly and abscised. Fructifications of a fungus in the genus Stemphylium were observed on young, as well as on old, lesions. The Stemphylium sp. was consistently isolated on potato dextrose agar from disease samples collected from five cultivars in 14 locations. In inoculation tests, the Stemphylium isolates from cotton were highly aggressive to cotton, tomato, potato, and blue lupines; whereas an isolate of $S$. solani from tomato was highly aggressive on tomato and potato but less aggressive on cotton. On the basis of its morphological, cultural, and pathogenic characteristics, the principal pathogen causing leaf blight symptoms was identified as Stemphylium solani. Epidemics caused by S. solani on cotton have not been reported previously in commercial cotton cultivation.
\end{abstract}

In southern Brazil, cotton is grown during the summer, i.e., between September and March. Based on the past 12 years of data, during these months the monthly average temperature is between 20.1 and $27.5^{\circ} \mathrm{C}$, and the monthly average rainfall varies between 47.8 and $347.7 \mathrm{~mm}$.

Cotton cultivars belonging to Gossypium hirsutum or to G. barbadense are susceptible to several foliar diseases caused by fungi and bacteria (16). A leaf spot caused by Alternaria macrospora was reported on cultivars belonging to $G$. barbadense and G. hirsutum (4,7). However, Alternaria alternata is more predominant on G. hirsutum under natural field conditions $(1,2,6)$. The leaf spot caused by A. alternata is the most prevalent foliar disease in southern Brazil and is considered to be a late-season disease of cotton. However leaf blight of cotton occurred early in the season in the state of Paraná, in the summer of 1994 and 1995, on the newly introduced $G$. hirsutum cultivar Paraná 3 (selection of IAC 20). In 1994, this cultivar occupied less than $10 \%$ of the cotton area; whereas in 1995 it occupied over $60 \%$ of the cotton area of the state (approximately 180,000 ha). In 1995, leaf blight symptoms different from those described for Alternaria leaf spot $(3,11,16)$ occurred throughout the

Corresponding author: Y. R. Mehta
E-mail: apviapar@iapar.pr.gov.br

Accepted for publication 22 December 1997.

Publication no. D-1998-0121-01R

(C) 1998 The American Phytopathological Society state, and no cotton field was free from this disease. The severity of the disease varied among cultivars, causing up to $100 \%$ yield losses in some commercial fields of Paraná 3.

The resistance of Paraná 3 to A. alternata observed consistently by cotton breeders over a period of 6 years in yield trials in Brazil (unpublished data) and the unusual and early occurrence of a severe leaf blight disease raised suspicions about the occurrence of a new foliar disease. This paper presents studies on the identification of the causal organism of this foliar disease and suggests some control measures to manage the disease.

\section{MATERIALS AND METHODS}

A field survey of cotton foliar diseases was conducted, and disease samples were collected from five cultivars from 14 different cotton regions of the state of Paraná during the 1995 to 1996 growing season. Isolations of the causal organism from the disease samples were made on petri plates containing potato dextrose agar (PDA) and incubated at room temperature in the laboratory. After 7 days of incubation, the most predominant fungal colonies were transferred to PDA slants and stored at $20^{\circ} \mathrm{C}$. Attempts were made to identify fungal cultures by culturing on PDA, V8 juice agar, and maltose peptone agar in combination with UV radiation $(5,10)$.

Pathogenicity tests of 37 individual isolates were made by preparing a suspension of mycelial fragments and conidia. Tenday-old colonies were gently scraped onto PDA with $20 \mathrm{ml}$ of sterile distilled water per plate. Fungal colonies grown on three plates per isolate were used for inoculum preparation. The suspension was filtered through cheesecloth, and a drop of Tween 20 was added.

Fifteen-day-old seedlings of cv. Paraná 3 , raised in a net-house, were uniformly inoculated until runoff with an atomizer, maintaining constant pressure, or inoculated with a soft paintbrush. Young plants of tomato (Lycopersicon esculentum) cv. Agricica, potato (Solanum tuberosum) cvs. Achat and Contenda, and one blue lupine (Lupinus angustifolius) cv. IAPAR-24, were also inoculated using one of the most aggressive isolates (No. 11687). Eight to 10 seedlings were inoculated with each test culture, and noninoculated control plants were sprayed with sterile water. Inoculated seedlings were incubated in a dew chamber for a period of $48 \mathrm{~h}$ at $21^{\circ} \mathrm{C}$ and then transferred to a net-house bench. In the nethouse, relative humidity ranged from 50 to $60 \%$ during the day and about $90 \%$ at night, and the day and night temperature means during the test period were 23 and $19^{\circ} \mathrm{C}$, respectively. The disease symptoms on inoculated plants were evaluated 12 days after inoculation, and the causal organism was reisolated from the necrotic lesions on PDA. Diseased leaf portions of $1 \times 0.5 \mathrm{~cm}$ were cut, surface-sterilized in $1 \%$ sodium hypochlorite ( $2 \%$ active $\mathrm{Cl})$, rinsed twice in sterile water for 1 to $2 \mathrm{~min}$, sliced into 2- to 3-mm sections, and transferred to petri dishes containing PDA. After 7 days incubation, the fungal colonies were compared with the original isolates. Assessment of disease intensity was made using a visual scale of 0 to 5 , where $0=$ no disease $; 1=$ minute pinhead size spots, less than $5 \%$ leaf tissue diseased; $2=$ small brown to dark brown necrotic lesions with no chlorosis, 5 to $25 \%$ diseased; $3=$ necrotic lesions with chlorosis, 26 to $50 \%$ diseased; $4=$ necrotic lesions with chlorosis, up to $10 \mathrm{~cm}$ diameter, usually coalescing, 51 to $75 \%$ diseased; and $5=$ lesions coalescing, $>76 \%$ diseased, and/or with desiccated and abscised leaves.

Reactions of $23 \mathrm{G}$. hirsutum cotton cultivars, including the old cultivars IAC 20 (selection of Auburn 50) and IAC 22 (IAC $20 \times \mathrm{GH} 11.9 .75$ ), to a mixture of five arbitrarily selected isolates of $S$. solani (culture collection nos. 11687, 11652, 118642, 11681, and 11660) were assessed by inoculating 15-day-old plants (two leaves per plant and a total of six plants per cultivar) grown in earthen pots of $20-\mathrm{cm}$ diameter containing a mixture of soil and organic manure (3:1 by volume). For this purpose, one seed of each cultivar taken from the genetic seed material obtained 
from the breeder's collection was grown in earthen pots in the net-house. Plants were selfed and grown to maturity, and the purified seeds thus obtained were used to study cultivar reaction.

Equal amounts of inoculum per isolate, i.e., fungal colonies grown under identical conditions and on equal numbers of PDA plates per isolate, were used. The spore concentration in the inoculum mixture was 8,500 spores per ml. After 48-h incubation in a dew chamber, the inoculated plants were transferred to the net-house and arranged in a randomized complete block design.

Plants were rated for disease severity 6 days after inoculation based on the percentage of leaf area infected. Leaves were detached, and areas of the visible necrotic lesions were traced on thin transparent plastic sheets with black ink and were assessed using the portable area meter, LiCOR, model LI-3000 (LAMDA Instruments Corp., Lincoln, NE). Percent leaf area infected (LAI) was calculated by dividing the area of the lesions by the total leaf area and multiplying by 100 . Disease severity data (LAI) were transformed in $\sqrt{\arcsin (\mathrm{LAI}+0.5) / 100}$ and subjected to analysis of variance. Mean separation was determined using the $t$ test (LSD) in SAS (SAS Institute, Cary, NC). The means of percentages of leaf area infected were classified as follows: 0 to $2.0=$ resistant; $>2.0$ $=$ intermediate-susceptible.

\section{RESULTS AND DISCUSSION}

Symptoms of the disease were observed 50 to 55 days after sowing and were characterized as small, circular to irregular, dark brown to black spots, varying between 2 and $5 \mathrm{~mm}$ and becoming reddish brown with age (Fig. 1). Fully developed lesions were up to $10 \mathrm{~mm}$ diameter with a whitish center and cracks, giving the appearance of a frog's eye. At a later stage, the cracked area dropped out, leaving a hole in the center of the lesion. In severely infected leaves, the lesions coalesced, and yellowing of the leaves occurred, and in a few days the leaves desiccated and abscised. No other symptoms were observed
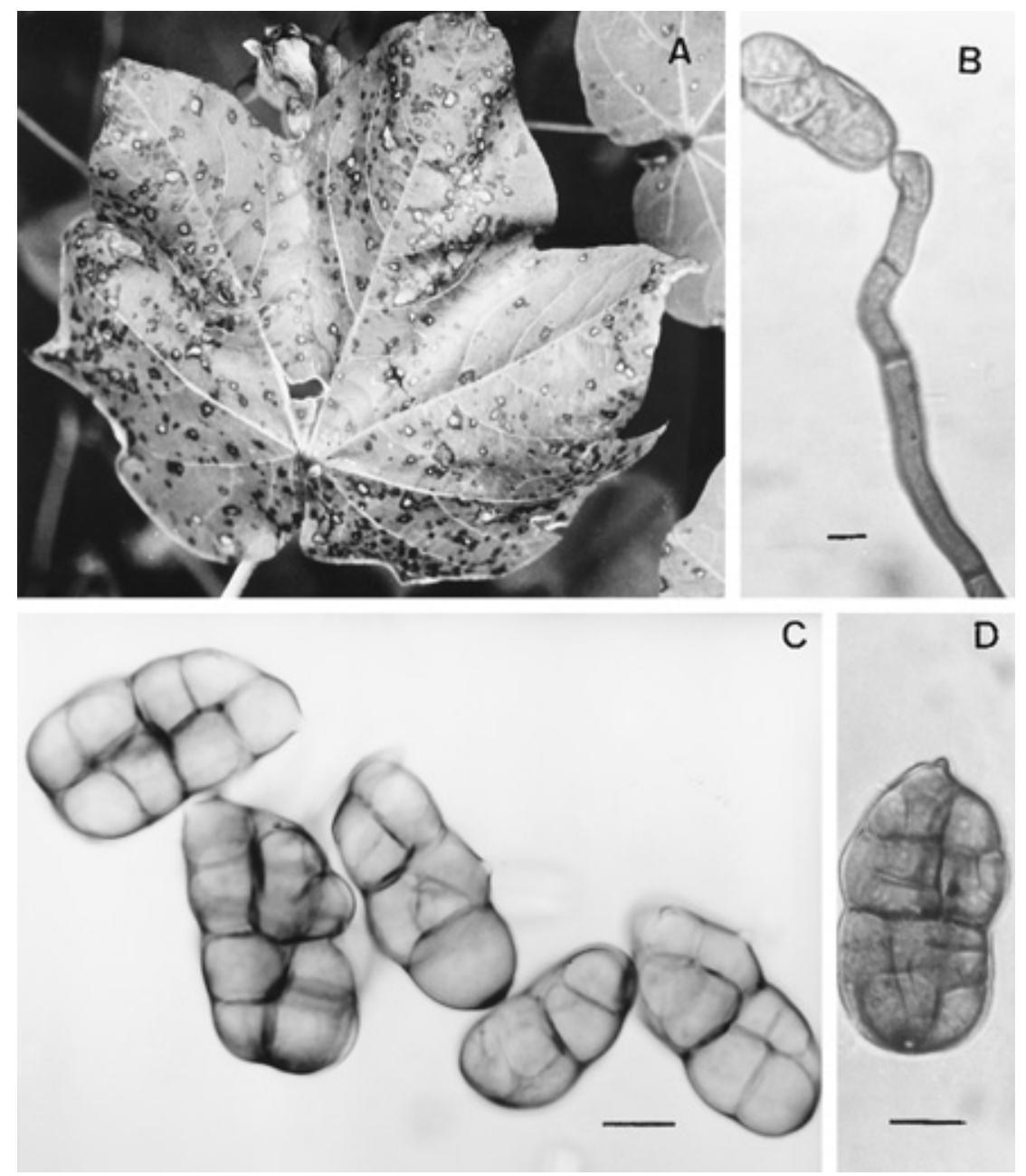

Fig. 1. (A) Stemphylium leaf spot symptoms on naturally infected cotton leaf; (B) conidium borne on a long conidiophore, from naturally infected leaf; $(\mathbf{C})$ conidia produced on PDA showing pronounced constriction at the middle septum; (D) fully mature conidium from naturally infected leaf showing rounded base and a whitish pore as the point of attachment to the conidiophore and a small pointed beak at the apex. Bar $=10 \mu \mathrm{m}$ on any other plant part. When examined under a stereomicroscope, fructifications of a fungus belonging to the genus Stemphylium were observed on lesions of various sizes in the form of conidiophores and conidia. Fructifications of other fungi, including Alternaria spp., were seldom observed on such lesions.

The severity of the disease was variable among cultivars. None of the old commercial cotton cultivars was as severely diseased as Paraná 3.

Of the 1,149 isolations made on PDA from the collected disease samples, $49.0 \%$ belonged to the genus Stemphylium and $1.4 \%$ to Alternaria. The rest belonged to the genera Corynespora, Curvularia, Helminthosporium, Phoma, or to other unidentified genera (Table 1). Thirty-six isolates of Stemphylium originating from different cultivars and locations were used to prepare monosporic cultures that were stored in a refrigerator for further studies.

In the pathogenicity tests, the first disease symptoms appeared 4 days after inoculation as small, sunken, circular to irregular spots on both spray-inoculated and brush-inoculated plants; however, the latter showed more severe symptoms. Well-developed disease lesions appeared 7 days after inoculation. Limited sporulation of the fungus, identical to that observed under field conditions, was observed 12 to 20 days after inoculation. However, abundant fructification was observed 45 to 60 days after inoculation on some leaves. Noninoculated control plants did not show any symptoms of disease. A Stemphylium sp. identical to the isolated fungus was isolated on PDA from the disease symptoms reproduced in the net-house. Inoculations were made with the reisolated fungus, and similar disease symptoms were once again reproduced. All 36 isolates of the Stemphylium sp. were pathogenic to Paraná 3 but differed in their degree of virulence. Two isolates were less aggressive and fell in disease-rating category 3 (26 to $50 \%$ leaf area diseased). Sixty-five percent of the isolates fell in category 4 (51 to $75 \%$ leaf area diseased), and $30 \%$ were in category 5 (>76\% leaf area diseased).

When inoculated with a mixture of five arbitrarily selected isolates, sharp differences in reaction among some cultivars were detected $(P=0.0001 ; \mathrm{LSD}=16.25)$. Cultivars IAC 22, Paraná 3, PR 94-216, Pr 94-529, and PR 94-601 showed complete susceptibility (almost 100\% leaf area infected and/or death of the leaf). Cultivars that showed complete resistance $(0.0 \%$ leaf area infected) were CNPA 87/61, CNPA Precoce 2, CNPA TB-46, PR 92-126, PR 94-215, PR 94-238, PR 94-608, PR 94204, and OC 94550. Nine other cultivars fell into the intermediate reaction group of $2.05-86.25 \%$ of the leaf area infected.

Only two isolates of $A$. alternata were pathogenic to cotton, causing mild symptoms characterized by small ( 1 to $2 \mathrm{~mm}$ ) 
circular lesions with dark brown margins and whitish centers. Isolates of Corynespora, Curvularia, Helminthosporium, and Phoma did not produce any disease symptoms.

On the artificial culture medium, none of the isolates of Stemphylium produced conidia in abundance, even when they were grown on PDA, V8 juice agar, and maltose peptone agar, under alternate cycle of 12-h light and 12-h darkness after having been subjected to UV radiation, as suggested by earlier workers for $S$. solani (5,8-10). Larger amounts of conidia were obtained when 7- to 10-day-old colonies grown in culture plates with a thin layer of PDA (10 ml/plate), were scraped, washed with water, and exposed to direct sunlight for 2 days ( $4 \mathrm{~h} /$ day).

Based on morphology of cultures grown on PDA, a range of different colony morphologies were found among the Stemphylium cotton isolates. Colonies were slow-growing on PDA, reaching 24 to 66 $\mathrm{mm}$ in diameter after 8 days of incubation, dark gray with sectors and with velvety centers of smooth and shiny mycelial mat, and produced a yellow pigment in the medium that turned deep red with age. However, pigment production was variable and isolate-dependent but was not related to the aggressiveness of the isolates. Observations and measurements of the fungus were made on naturally infected leaves. Conidiophores were found to be erect, brown with vascular swellings, 5 to 8 septa, bearing a single conidium at the apex, and measuring 95 to $117 \times 5$ to $6 \mu \mathrm{m}$. Conidia were oblong, smooth-walled, pointed at the apex showing a small beak, rounded at the base with the basal part dark brown to black showing a white pore where it attached to the conidiophore. The golden brown conidia most commonly had three transverse septa, rarely four, a pronounced constriction at the middle septum with several longitudinal irregular septa, and measured 40 to $50 \times 20$ to $25 \mu \mathrm{m}$ (Fig. 1). The cultural, morphological, and pathogenic characteristics of the pathogen were similar to those described for Stemphylium solani on tomato and/or potato, and hence the principal pathogen causing leaf blight symptoms on cotton was identified as Stemphylium solani Weber. The sizes of the conidiophores and the conidia as reported by Weber (17), CMI (3), and Jones et al. (8) were 130 to $200 \times 4$ to $7 \mu \mathrm{m}$ and 35 to $55 \times 20$ to $28 \mu \mathrm{m}$, respectively. The identification was further confirmed by the International Mycological Institute, U.K., where the disease specimens and cultures of the pathogen are deposited under the IMI nos. 373328 and 373329.

Although the gross morphological characteristics and the conidial dimensions of the causal organism are very closely related to S. solani, the conidia of our isolates are slightly shorter and narrower, smooth walled in contrast to the verrucose walls of $S$. solani, and showed abundant germination from cells of the conidia throughout the conidium body - $\mathrm{a}$ feature that has not been reported before in $S$. solani (J. C. David, personal communication) (Fig. 2). The cultural characteristics of tomato isolates were different from those of the cotton isolates, i.e., the colonies of tomato isolates were smooth, circular, lacking sectors, and had white to pink aerial mycelium. In the cross-inoculation tests, isolates of $S$. solani from cotton were pathogenic on cotton, tomato, potato, and blue lupines. An isolate of $S$. solani from tomato was also pathogenic to tomato and potato but was less aggressive to cotton. Based on such morphological and pathological differences, it is believed that the present organism is a new strain of $S$. solani attacking cotton in Brazil.

The Stemphylium leaf spot epidemic was correlated with the release and rapid expansion of area under cultivation to the highly susceptible cultivar Paraná 3 , along with the excessive rains during the crop cycle. The average monthly rainfall was approximately 108 to $348 \mathrm{~mm}$, and the average monthly temperature was approximately 22 to $25^{\circ} \mathrm{C}$ during the 1995 to 1996 crop cycle. Although precise origin of the pathogen, as well as the survival mechanism of the pathogen, are unknown, it seems likely that the primary infection comes from airborne conidia produced on other hosts.

A leaf spot disease of cotton caused by a Stemphylium sp., probably S. bortyosum, was reported in the United States (14); however, detailed descriptions of the pathogen were not presented by these authors. Later, Morgan-Jones and Sinclair (13) reported a leaf spot of cotton caused by $S$. solani in the state of Louisiana but did not provide details about its occurrence or its economic importance. A leaf spot of cotton caused by $S$. macrosporideum was also reported in Ukraine and its neighboring states (15). Since no other report of $S$. solani on commercial cotton has been reported in the literature, it is likely that the disease is indigenous and remained unrecorded for some time in Brazil. Nonetheless, the possibility of having introduced the pathogen through imported germ plasm cannot be ruled out.

The disease can be managed through the planting of resistant cultivars, as identified during the present investigation, along with one or two foliar applications of an appropriate fungicide. Since the disease poses a threat to cotton cultivation in this region, efforts should be directed toward the identification of the sources of resistance and the maximum diversification of the germ plasm.

According to the preliminary field trials conducted at two locations (12), disease intensity was significantly lower in plots sprayed twice with the fungicide fentin hydroxide- $40 \%$ at $200 \mathrm{~g}$ a.i./ $/ \mathrm{ha}^{-1}$ and fentin acetate- $20 \%$ at $200 \mathrm{~g}$ a.i. $/ \mathrm{ha}^{-1}$ at a 15 -day interval, starting the first application 57 days after sowing. Plots sprayed with difenoconazole, tebuconazole, difenoconazole + propiconazole, and mancozeb did not differ from unsprayed control plots, but they differed from plots sprayed with fentin hydroxide and fentin acetate, using

Table 1. Isolation of causal organism from leaf blight samples collected from five cotton cultivars grown at 14 different locations in the state of Paraná, Brazil, during 1995 and 1996

\begin{tabular}{|c|c|c|c|c|c|c|}
\hline & \multirow[b]{2}{*}{ Location } & \multirow[b]{2}{*}{ Cultivar } & \multirow{2}{*}{$\begin{array}{l}\text { Isolations } \\
\text { per sample }\end{array}$} & \multicolumn{3}{|c|}{$\begin{array}{l}\text { Colonies growing on potato dextrose } \\
\text { agar after } 7 \text { days incubation }(\%)\end{array}$} \\
\hline & & & & Stemphylium sp. & Alternaria sp. & Others $^{\mathrm{a}}$ \\
\hline 1 & Londrina/Field I & Paraná 3 & 506 & 56 & 4 & 40 \\
\hline 2 & Londrina/Field II & Paraná 3 & 152 & 12 & 4 & 83 \\
\hline 3 & São Pedro & Paraná 3 & 30 & 33 & 3 & 63 \\
\hline 4 & São Pedro & IAC 20 & 30 & 13 & 7 & 80 \\
\hline 5 & Iracema d'Oeste & Paraná 3 & 79 & 68 & 2 & 30 \\
\hline 6 & Maringá & Paraná 3 & 26 & 31 & 0 & 69 \\
\hline 7 & Maringá & OC $92-183$ & 30 & 30 & 0 & 70 \\
\hline 8 & Maringá & IAC 20 & 30 & 33 & 0 & 67 \\
\hline 9 & Maringá & PR 92-122 & 15 & 40 & 0 & 60 \\
\hline 10 & Goioerê & OC $92-183$ & 50 & 17 & 0 & 83 \\
\hline 11 & Goioerê & IAC 22 & 7 & 71 & 0 & 29 \\
\hline 12 & Goioerê & IAC 20 & 12 & 50 & 0 & 50 \\
\hline 13 & Goioerê & PR 92-122 & 16 & 94 & 0 & 6 \\
\hline 14 & Goioerê & Paraná 3 & 19 & 47 & 0 & 53 \\
\hline 15 & Formosa d'Oeste & IAC 20 & 21 & 67 & 0 & 33 \\
\hline 16 & Formosa d'Oeste & Paraná 3 & 13 & 69 & 0 & 31 \\
\hline 17 & Juranda & IAC 20 & 15 & 73 & 0 & 27 \\
\hline 18 & Jesuíta & Paraná 3 & 10 & 20 & 0 & 80 \\
\hline 19 & Terra Nv. d'Oeste & Paraná 3 & 16 & 94 & 0 & 6 \\
\hline 20 & Janiópolis & Unknown & 4 & 50 & 0 & 50 \\
\hline 21 & Nova Aurora & Unknown & 15 & 33 & 0 & 67 \\
\hline 22 & A. Chateaubriand & Unknown & 22 & 46 & 0 & 55 \\
\hline 23 & Boa Esperança & Unknown & 15 & 53 & 13 & 33 \\
\hline \multirow[t]{2}{*}{24} & Band d'Oeste & Unknown & 16 & 75 & 0 & 25 \\
\hline & & Average & & 49 & 1 & 50 \\
\hline
\end{tabular}

a Other fungal genera. 


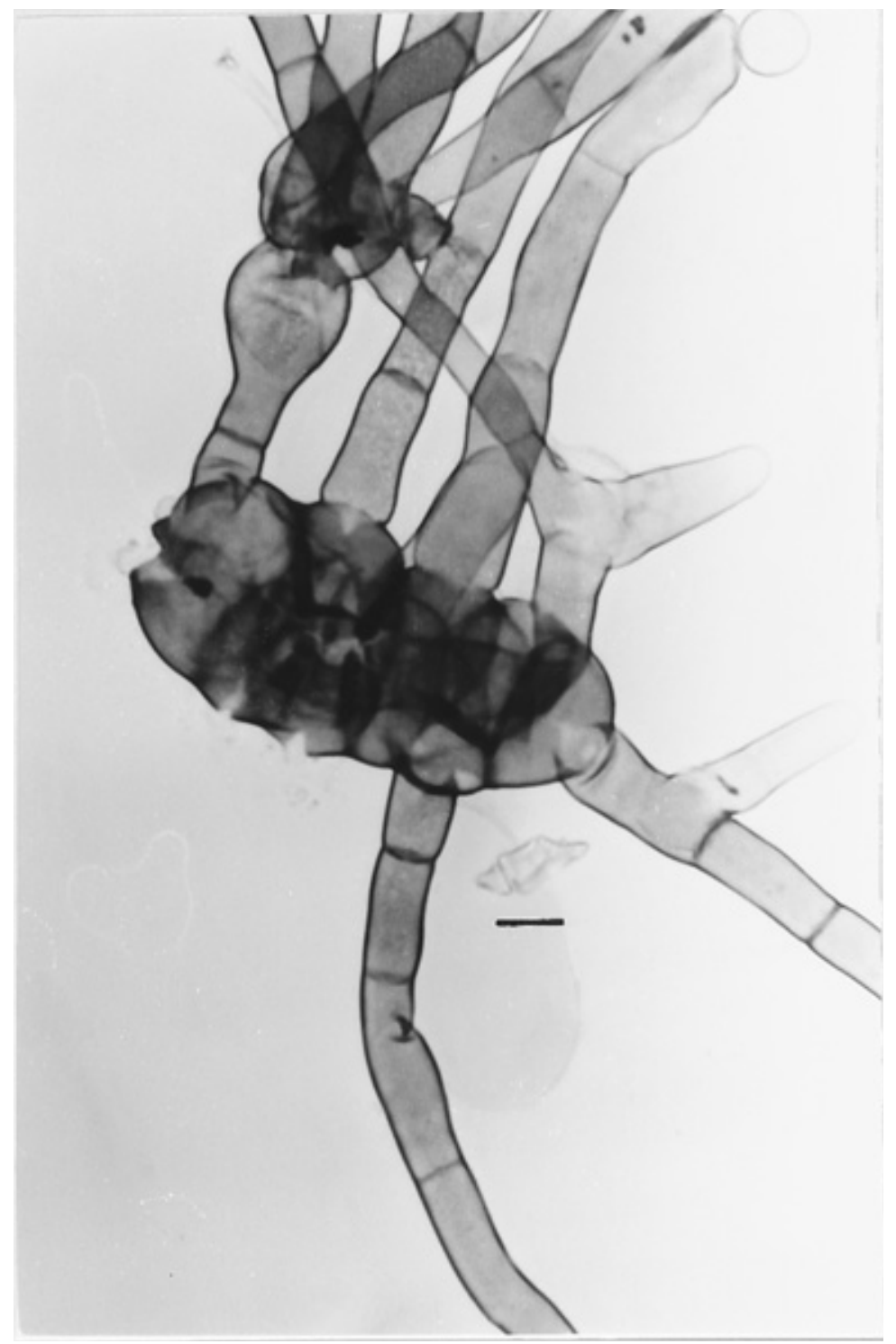

Fig. 2. Germination from cells of conidium of Stemphylium solani of cotton throughout the conidium. $\mathrm{Bar}=10 \mu \mathrm{m}$

either the average percentage of the leaf area diseased or the average number of lesions per leaf. Although the disease could be controlled through the use of fungicides, the differences in yield were not significant. Further work is necessary to determine the appropriate timing of fungicide applications.

\section{ACKNOWLEDGMENTS}

I thank C. Kurozawa for providing the S. solani isolate from tomato; Nelson S. Fonseca, Jr., for his help in statistical analysis; and R. S. Yamaoka, W. P. Almeida, and J. R. Pires for collaborating in collecting the disease samples. Technical assistance was provided by T. K. K. Tame, J. A. Oliveira, S. P. Muramoto, T., A. Souza, and E. H. Ota.

\section{LITERATURE CITED}

1. Bashan, Y. 1986. Phenols in cotton seedlings resistant and susceptible to Alternaria macrospora. J. Phytopathol. 116:1-10.

2. Bashi, E., Rotem, J., Pinnschmidt, H., and Kranz, J. 1983. Influence of controlled environment and age on development of Alternaria macrospora and on shedding of leaves in cotton. Phytopathology 73:1145-1147.

3. Commonwealth Mycological Institute. 1975. CMI Descriptions of pathogenic fungi and bacteria. Stemphylium solani. Set 48, CM Sheet No. 472. Commonw. Mycol. Inst., Surrey, Eng.

4. Cotty, P. J. 1987. Evaluation of cotton cultivar susceptibility to Alternaria leaf spot. Plant Dis. 71:1082-1084.

5. Diener, U. L. 1955. Sporulation in pure culture by Stemphylium solani. Phytopathology 45:141-145.

6. Ephrath, J. E., Shteinberg, D., Drieshpoun, J., Dinoor, A., and Marani, A. 1989. Alternaria alternata in cotton (Gossypium hirsutum) cv. Acala: Effects on gas exchange, yield components and yield accumulation. Neth. J. Plant Pathol. 95:157-166.

7. Hillocks, R. J., and Chinodya, R. 1989. The relationship between Alternaria leaf spot and potassium deficiency causing premature defoliation of cotton. Plant Pathol. 38:502-508.

8. Jones, J. B., Jones, J. P., Stall, R. E., and Zitter, T. A. 1991. Compendium of Tomato Diseases. American Phytopathological Society, St. Paul, MN

9. Kurozawa, C., and Mussi, L. 1995. Avaliação de resistência em cultivares e híbridos de tomateiro à mancha-de-estenfílio. Summa Phytopathol. 21:199-201.

10. Lima, D. M. M. 1982. Maltose-peptone-agar, um meio de cultura para esporulação de Stemphylium solani. Pesqui. Agropequ. Bras. 17:81-83.

11. Ling, L., and Yang, J. Y. 1940. Stem blight of cotton caused by Alternaria macrospora. Phytopathology 31:664-671.

12. Mehta, Y. R., and Oliveira, M. A. 1996 Avaliação da eficiência de fungicidas no controle da mancha preta do algodoeiro. (Abstr.) Fitopatol. Bras. 21(supl.):371

13. Morgan-Jones, G., and Sinclair, C. 1978 Fungi of Alabama VII. Dematiaceous hypomycetes. J. Ala. Acad. Sci. 49(1):1-15.

14. Sinclair, G. B., and Shatla, M. N. 1962. Stemphylium leaf spot of cotton reported from Louisiana. Plant Dis. Rep. 46:744.

15. Tagirova, V. A., and Karimov, K. H. M. 1991. Pink-raspberry rot of cotton fiber. (Abstr. in English) Zashch. Rast. Moskva No. 3, 47 pp.

16. Watkins, G. M., ed. 1981. Compendium of Cotton Diseases. American Phytopathological Society, St. Paul, MN.

17. Weber, F. G. 1930. Gray leaf spot of tomato caused by Stemphylium solani sp. nov. Phytopathology 20:513-518. 